\title{
Белинский о Квитке
}

\author{
ВИКТОРИЯ ЛЕБОВИЧ \\ ELTE BTK Ukrán Filológiai Tanszék, H-1088 Budapest, Múzeum krt. 4/D. \\ E-mail: leboviki@gmail.com
}

(Received: 23 August 2019; accepted: 25 October 2019)

Юрий Бойко в своей статье «Белинский и украинское национальное возрождение», опубликованной в 1953 году, отмечает, что с украинскими писателями, которых В. Г. Белинский считал опасными кандидатами в идеологи украинства (например, с Костомаровым или Метлинским), критик жестоко расправлялся, в то время как с теми, которые писали и по-русски, осторожничал, побуждая их писать только на русском языке (Бойко 1992: 90-91).

Ко второй категории писателей относится и первый прозаик новой украинской литературы XIX века Григорий Квитка-Основьяненко. Рассмотрим оценку творчества писателя, которая вырисовывается в статьях, заметках и рецензиях 1838-1846 гг. известного русского литературного критика, Виссариона Григорьевича Белинского (1811-1848), о котором Ю. Сорокин писал, что в начале сороковых годов его деятельность достигла своего апогея. «Имя Белинского и выражение „критика Отечественных записок“ были синонимами» (Сорокин 1981: 622).

Уже в 1838 году по поводу рассказа Г. Квитки-Основьяненко «Салдацький патрет» (1833), который в прекрасном - по словам Белинского - переводе Луганского на русский язык был помещен в VII томе «Современника» (БЕлинский 1977: 570-571), критик следующими словами увещевает Квитку писать не по-малороссийски:

...мы, москали, немного горды, а еще более того ленивы, чтобы принуждать себя к пониманию красот малороссийского наречия, если дело идет не о народной поэзии. Ведь Гоголь умеет же рисовать нам малороссиян русским языком? Уверяем почтеного Грицьку Основьяненка, что если бы он написал свои прекрасные повести по-русски, то, несмотря на мудренную для выговора фамилию своего автора, они доставили бы ему гораздо большую известность, нежели какою он пользуется на Руси, пиша по-малороссийски (БЕлинский 1977: 275-276).

В том же 1838 году в критике на журнал «Современник» В. Белинский обращается к повести Г. Квитки-Основьяненко «Маруся» (1832). И начинает с того, что он не в состоянии выразить наслаждения, доставленного ему прочтением опять же прекрасного русского перевода произведения, которое критик называет «чудной повестью», а также подчеркивает единодушные 
похвалы всех литературных журналов и общий восторг публики (БЕлинский 1977: 385).

Повесть «Маруся» действительно с восторгом восприняли украинцысовременники. М. Максимович, например, писал, что воспитанным в пансионатах благородных девиц малороссиянкам не стоит отворачиваться от прекрасной героини Квитки, именно им следует читать произведение «смакуючи і плачучи» (МАксимович 1961: 217). Оценка Максимовича словно оправдывает повод, побудивший Квитку написать произведение, сформулированный автором 15 марта 1839 г. в письме к П. А. Плетневу. Намерением Квитки было доказать в споре с П. Гулаком-Артемовским, что на малороссийском языке можно писать литературные произведения, в том числе и такие, от которых у читателей выступят слезы на глазах (КвитКА-ОсновьянЕнко 1981: 215).

Все это не что иное, как продолжение полемики о существовании малороссийского языка, которая достаточно оживленно велась в первой половине XIX века. М. Лескинен в работе «Земля, текущая медом и молоком»: украинские земли Правобережья в представлениях региональных элит и политике имперских властей в первой половине XIX в.» пишет, что все это является проявлением существующего в те времена в России интереса к украинской культуре, в том числе и словесности, вызванного становлением украинской нации, сопровождаемым ростом национального самосознания. Политически же это привело к столкновению

разных концепций модерной (национальной и наднациональной) идентичности, разрабатываемых «сверху» имперской российской элитой и региональной польской, и противостоящей им «снизу» традиционной (этнографической) идентичности украинского населения, по преимуществу крестьянского (ЛЕскинЕН 2018: 164).

А В. Соколова пишет:

Восточнославянские литературы (русская, украинская и белорусская) в силу определенных социально-исторических условий находились на разных уровнях развития, и с начала XIX в. в петербургских литературных кругах неоднократно вставал вопрос о языках, родственных русскому и об их праве на сосуществование с языком русским. Особый резонанс получила развернувшаяся в 1815 г. полемика между редактором «Русского вестника» М. Т. Каченовским и профессором Краковского университета Г. С. Бандтке, доказывавшим самостоятельное значение украинского языка и его независимость от русского (СоколовА 2011).

Соколова цитирует М. Т. Каченовского, который сформулировал мысль о том, что малороссийский язык «способен только к шуточным сочинениям». Каченовский добавляет, что даже великорусский язык, на котором уже написано много самых различных произведений, «далек от совершенства». Так неужели малороссийский язык сумеет справиться с ожидающими его «непреодолимыми» трудностями, задает риторический вопрос критик (см. СоколовА 2011). 
Подобные утверждения оспаривает и опровергает своим творчеством Квитка-Основьяненко.

А Белинский похвалу, написанную в адрес повести «Маруся» в критике на журнал «Современник», считает лишь проявлением личного вкуса и субъективной оценки, в то время как «суждение о предмете должно браться из самого судимого предмета», ведь

Похвала, хотя сколько-нибудь превышающая истинное достоинство произведения, не возвышает, а унижает его, и вообще преувеличенные похвалы, после, когда пройдет восторг, нередко бывают причиною столь же или еще и более несправедливых или незаслуженных порицаний (БЕлинский 1977: 385).

«Марусю» критик считает не художественным, а только поэтическим произведением, объясняя, что поэтическим следует считать все «проникнутое душою, согретое чувством». Персонажи повести по мнению критика это идеализированные образцовые типы малороссиян, которым недостает индивидуализации: «перед вами рисуются силуэты, очерки, а не портреты; бюсты, а не живые лица». А художественность в толковании Белинского это способность «одним словом живо и полно» выразить то, что «не выразишь и в десяти томах» (БЕлинский 1977: 385-386). Поэтическую прелесть и заманчивость повести Белинский видит в самой Малороссии, ее обычаях, природе, жизни малороссийского народа. Заканчивает свой экскурс Белинский и на этот раз напоминанием о том, что автору лучше было бы писать свои произведения на русском языке:

Издатель «Современника» оказал своим читателям неоцененную услугу, давши им возможность насладится этою прекрасною повестью, которая была им недоступна по причине наречия, на котором написана своим автором (БЕлинский 1977: 388).

В качестве опосредственного побуждения писать на русском языке может быть воспринята и похвала, звучащая в заметке Белинского «Журналистика», резко критикующей журнал «Сын Отечества». В ответ на жалобу «Сына Отечества» по поводу того, что Квитка-Основьяненко ничего по-русски не пишет, Белинский ссылается на повести «Пан Халявский» (1840) и «Головатый» (1839), опубликованные в «Отечественных записках», и другие произведения, напечатанные в «Современнике», после чего язвительно спрашивает: «Уж не потому ли Основьяненко перестал писать по-русски, что не хочет ни одной строчки своей поместить в «Сыне Отечества?..» (БЕлинский 1978: 420). В конце статьи, в которой «мнения» «Сына Отечества» Белинский называет «случайными, произвольными, чуждыми всякого критериума» (БЕлинский 1978: 415), критик повторяет:

Сочинения Основьяненко на русском языке «Сын Отечества» может видеть в «Отечественных записках», в «Современнике», в «Утренней заре» г. Владиславлева, и может быть, в других изданиях, только не в себе самом, где их нечего искать (БЕлинский 1978: 424). 
И в качестве убедительного завершения констатирует: «Они писаны русским, и притом хорошим русским языком» (БЕлинский 1978: 424).

В конце 1830-х - начале 1840-х гг. В. Белинский в ряде своих работ не раз отзывался положительно о Квитке-Основьяненко и его произведениях. Так, например, в рецензии 1840 г. на «Полное собрание сочинений А. Марлинского» Белинский причисляет Г. Квитку-Основьяненко к именам «более или менее блестящих и сильных талантов» (БЕлинский 1978: 209). А в статье «Русская литература в 1840 году» Белинский писал: «Талантливый Основьяненко напечатал в „Современнике“ несколько интересных повестей [«Козырь-девка» (1838): Т. XVII; «Украинские дипломаты»: Т. XVIII; «Панна сотниковна» (1839): Т. XIX; «Ярмарка» (1840): Т. XX - В. Л.] и живую, остроумную журнальную статью „Званые гости“» (1840) (БЕлинский 1978: 209). В работе «Русские журналы», в отзыве о «Современнике», всегда богатом по мнению Белинского оригинальными статьями, что придает журналу «высокую цену» (БЕлинский 1977: 407), упоминается «перевод с малороссийского наречия на русский язык одного из милых юмористических рассказов талантливого Грицька Основьяненка» (БЕлинский 1977: 408). Здесь речь идет о рассказе «Мертвецький великдень» (1833). В журнале «Утренняя зоря» за 1840 год к категории «прекрасных статей в прозе и стихах» Белинский относит рассказ Квитки-Основьяненко «Божі діти» (1840), который по его мнению отличается «увлекательною простотою и оригинальным слогом» (БЕлинский 1977: 513).

В то же время о русскоязычных произведениях Квитки-Основьяненеко, написанных в 20-х гг. XIX в., Белинский отзывается уже далеко не настолько лестно. В статье «Пантеон русского и всех европейских театров» панданту гоголевского «Ревизора», пьесе «Приезжий из столицы, или Суматоха в уездном городе» критик уделяет совсем немного внимания: всего один абзац, в котором недвусмысленно намекает на несовершенство произведения:

Оригинальная комедия в пяти действиях, сочинение Грыцько Основьяненко, написанное им еще в 1827 году. Мы так высоко уважаем прекрасный талант Грыцька Основьяненко, что ничего не скажем об этом его произведении, которого талантливый автор очень и очень не без причины не хотел так долго печатать (БЕлинский 1978: 408).

В обзорной статье «Русская литература в 1841 году» критике подвергаются две комедии «Дворянские выборы» (1828), которые Белинский считал «сколком с комедий Фонвизина и в достоинствах и в недостатках» (БЕлинский 1979а: 291). И дальше критик выносит вердикт: «но складывать и изобретать две вещи розные; притом же все хорошо в свое время, - и честь и слава уму и таланту Фонвизина, что он угадал, что можно и что нужно было в его время...» (БЕлинский 1979а: 291). Пару лет спустя, в 1845 г. Белинский в статье «Мысли и заметки о русской литературе» повторяет это свое мнение, когда называет комедии Фонвизина «Недоросль» и «Бригадир» гениальными, хотя и не совсем художественными произведениями. А «Дворянские 
выборы» по мнению критика со своими «недостатками, но и не без достоинств» оказались лишь слишком поздним подражанием Фонвизину (БЕлинСКИй 1982а: 55).

Рецензию на написанный также на русском языке роман Г. Квитки-Основьяненко «Жизнь и похождения Петра Степанова, сына Столбикова, помещика в трех наместничествах. Рукопись XVIII века» (1841) Белинский начинает следующими словами: «Не понимаем, что за охота такому почтенному и талантливому писателю, как г. Основьяненко, тратить время и труд на изображение глупцов, подобных Столбикову» (БЕлинский 1979а: 498). Объяснение появлению в русской литературе неприемлемых с точки зрения критика произведений, в которых «элементы комического» рождаются в карикатурах и преувеличениях, а не берутся из действительности, Белинский находит с одной стороны в провинциальности автора, а с другой - в давно уже устаревшей в столице критике галломании общества (БЕлинский 1979a: 498-499).

В статье «Похождения Чичикова, или Мертвые души» Белинский подвергает уничтожающей критике почти всю русскую литературу, кроме произведений Пушкина, Лермонтова и Гоголя.

Какое-то апатическое уныние овладело литературою; торжество посредственности было полное; видя, что никто ей не мешает, она овладела и романом, и повестью, и театром (БЕлинский 1979b: 50).

И хотя в тексте статьи критик не называет ни авторов, ни произведения, когда ссылается на «длинную фалангу уродов и недоносков», нетрудно понять, что под произведением, в котором автор выдает «нам за народность грязь простонародья, за патриотизм сало и галушки, а за юмор и остроумие карикатуры нигде не бывалых идиотов, которые, по воле г. сочинителя, то глупы, то умны, то опять глупы», следует понимать роман Квитки-Основьяненко «Жизнь и похождения Петра Степанова, сына Столбикова, помещика в трех наместничествах» (БЕлинский 1979b: 50).

Рецензию, написанную в 1841 году под названием «Ластовка. Сочинения на малороссийском языке. Сватанье. Малороссийская опера в трех действиях», Белинский посвящает одновременно альманаху произведений украинских авторов и малороссийской опере Г. Квитки-Основьяненко «Сватання на Гончарівці» (1835) постольку, поскольку «обе они писаны на малороссийском наречии» (БЕлинский 1979а: 416).

Вероятно именно благодаря альманаху «Ластівка» удалось В. Белинскому отождествить псевдоним Грыцько Основьяненко с Григорием Квиткой. На основе посвящения повести «Сердешна Оксана» (1841) («Любій моїй жінці, Анні Григорівні Квітка»), напечатанной в альманахе, Белинский делает вывод, что

г. Основьяненко и г. Квитка - одно и то же лицо, ибо «жинка», или «жинца», по-малороссийски значит «жена». Итак, все эти повести и романы, которые печатались под именем Основьяненка, принадлежат г-ну Квитке, принявшему только в виде псевдонима имя Основьяненка?.. (БЕлинский 1979а: 418). 
В начале рецензии Белинский формулирует два вопроса, которые безусловно определяют его подход к украинской словесности вообще. Первый вопрос: «есть ли на свете малороссийский язык, или это только областное наречие?» Из ответа на него вытекает второй вопрос: «может ли существовать малороссийская литература и должны ли наши литераторы из малороссиян писать по-малороссийски?». Критик считает, что малороссийский язык существовал и существует, но только в ценных и достойных сохранения памятниках народной поэзии. А со времен Петра I - по мнению Белинского из-за разделения сословий дворяне стали говорить на русском языке, параллельно с чем малороссийский язык «народа начал портиться». В конце умозаключений рождается категорический и весьма несправедливый вывод:

Следовательно, мы имеем полное право сказать, что теперь уже нет малороссийского языка, а есть областное малороссийское наречие, как есть белорусское, сибирское и другие, подобные им областные наречия (БЕлинский 1979а: 416-417).

Впрочем Малороссию Белинский и в данном случае восхваляет как страну поэтическую и в высшей степени оригинальную: обильным источником поэзии, считает критик, является неподражаемый юмор народа, любовь, как основная стихия жизни, «азиатское рыцарство удалого казачества», тревожная жизнь малороссиян и борьба с католиками и бусурманами (БЕлинский 1979a: 416).

Оценкой же малороссийской оперы «Сватання на Гончарівці» оказывается всего одно, последнее предложение рецензии:

Что касается до «Сватанья» г. Основьяненка, или г. Квитки, - это водевиль из крестьянского быта, водевиль, впрочем, довольно растянутый, но местами не без занимательности (БЕлинский 1979а: 418).

Из всех произведений Григория Квитки-Основьяненка наибольшее внимание В. Белинский уделил русскоязычной сатирической повести «Пан Халявский». На это произведение критик ссылается даже в рецензии на такое издание, как книга Я. Юдицкого «Способ к распространению шелководства». Белинский практически отказывается рецензировать книгу, ссылаясь на то, что «долг рецензента изложить содержание» рецензируемой книги, но никто не вправе ни у кого требовать прочтения настолько плохо написанной книги, которая способна любого «отвратить от всякого чтения» (БЕлинский 1977: 473). И вместо того, чтобы написать рецензию на издание Я. Юдицкого, критик излагает свои мысли о русской словесности, о необходимости учить учеников естественному, простому, живому и правильному слогу, наряду «с легкостью изложения мысли» о предметах, не выходящих «из сферы их понятий и их жизни». Отвергая риторику, и называя ее «учением о хриях и рассуждениях», Белинский призывает избавиться от нее как от «педантической гнили и пыли, как гибели всего естественного, простого». О риторике по мнению 
критика нужно хранить только воспоминание, «подобно факту старины, вместе с школьными преданиями о палях, суботках и прочем, о чем так забавно рассказывает „Пан Халявский“» (БЕлинский 1977: 471).

В работе посвященной анализу русской литературы в 1840 году сатирический роман Квитки-Основьяненко «Пан Халявский» Белинский назвал превосходной сатирой, написанной рукою отличного мастера (БЕлинский 1977: 214). А в конце 1840 года в небольшой заметке «Сочинения Основьяненка» Белинский прямо высказывает автору благодарность за спасение «Библиографической хроники» декабрьского номера «Отечественных записок» «от горькой участи быть роковым, последним месяцем чахоточной литературы». Белинский пишет, что Квитка-Основьяненко «своим забавным», «полным, оконченным» «Паном Халявским» оживляет и воскрешает литературу благодаря тому, что журнал уже в декабре начинает печатать сатирическую повесть (БЕЛИНСКИй 1978: 462).

Остроумному Основьяненку пришла в голову счастливая мысль - сравнить прошедшее время с настоящим, заставив человека прошлого века рассказывать про жизнь своих «дражайших родителей», свое воспитание и про всю свою жизнь. Этот человек - род малороссийского Митрофанушки, и он выполнил задачу автора как нельзя лучше: словно на ладони видите вы почтенную старину, преисполненную невежества, лени, обжорства и предрассудков; видите, как глупый муж бьет свою глупую жену и тузит детей; как глупая мать насмерть закармливает своих милых деток, а детки дерутся друг с другом за всякий кусок, обманывают отца и мать и, выросши, заводят друг с другом процессы и творят друг другу всевозможные обиды (БЕлинский 1978: 462).

Завершает этот краткий анализ произведения предложение, которое по сей день цитируется практически во всех украинских литературоведческих работах, посвященных жизни и творчеству Григория Квитки-Основьяненко: «Кто смешлив от природы, советуем не читать „Пана Халявского“, если боится заболеть от хохота: уморительнее ничего нельзя выдумать» (БЕлинский 1978: 462).

В 1841 году в статье «Общая идея народной поэзии» Белинский все еще положительно отзывается о повести:

Мы отдаем полную справедливость юмористическому таланту, с каким написан «Пан Халявский» г. Основьяненка; еще выше ценим прекрасную цель, с какою написана эта забавная сатира на доброе старое время (БЕлинский 1979а: 139),

однако другие произведения автора ругает за то, что «в них мужики говорят чистым мужицким языком и никак не выходят из ограниченной сферы своих понятий» (БЕЛинский 1979а: 139).

Обзор «Русская литература в 1843 году» характеризуют сетования Белинского по поводу состояния русской литературы: «Литература наша находится в состоянии кризиса: это не подвержено никакому сомнению» (БЕлинский 1981: 7). По мнению критика в русской литературе в 1839 г. произошел 
перелом, так как стало выходить намного меньше книг и литература стала беднее прежнего. Перечисляя издания этого периода критик дает опять-таки далеко нелестную характеристику уже ушедшему к тому моменту из жизни Квитке:

В числе молодых с 1838 года явился один старый: это покойный Основьяненко, между бесчисленными повестями которого, написанными в продолжение какихнибудь четырех лет, особенно замечателен «Пан Халявский» - сатирическая картина старинных нравов Малороссии; во всех других повестях и романах своих он повторял или сентиментальность своей «Маруси», или юмор «Пана Халявского» и в последнее время значительно выписался (БЕлинский 1981: 20).

В рецензии на роман шведской писательницы Фредерики Бремер «Семейство, или домашние радости и огорчения» Белинский иронизирует над журналом «Современник», что приводит к разрыву с П. А. Плетневым. В отношении публикации произведений Квитки в журнале Белинский пишет:

Бывало, изобильно снабжал его повестями и рассказами Основьяненко: в каждой книжке «Современника» (а тогда он выходил в числе четырех книжек ежегодно), читатели его находили повесть г. Основьяненко, а иногда и две (БЕлинский 1981: 428).

\section{И язвительно продолжает:}

Видя такую плодовитость малороссийского писателя, даже мы, люди посторонние в отношении к «Современнику», чуть было не поверили достоверности вдруг пронесшегося слуха, будто Основьяненко - первый писатель русский... Но в 1942 году нескончаемая нить повестей и рассказов г. Основьяненко вдруг прервалась. Чьи повести будет теперь печатать «Современник»? (БЕлинский 1981: 428).

После смерти Г. Квитки-Основьяненко Белинский предпочитает уже не церемонится с автором, и, например, произведение «Вояжеры» называет «quasi-комедией г. Основьяненко» и характеризует, как «высокий образец бездарности и плохого вкуса» (БЕлинский 1982a: 22).

Искреннее же мнение о сатирической повести «Пан Халявский» Белинский, вероятнее всего, сформулировал в письме к А. А. Краевскому (18101889) еще 19 августа 1839 года, незадолго до того, как в вышеупомянутой статье о состоянии литературы в 1840 году высказал Квитке благодарность за спасение библиографической хроники «Отечественных записок» и высоко оценил произведение. Опубликованное в печатных органах мнение известного русского критика резко противоречит мнению, изложенному в письме:

«Пан Халявский» для первого чтения потешен и забавен, но при втором чтении с него немного тошнит. Это не творчество, а штучная работа. [...] Впрочем, для журнала «Халявский» - клад: он найдет себе больше читателей и хвалителей, чем творческие произведения Гоголя (БЕлинский 1982b: 247). 
Итак, с одной стороны «прекрасный талант» и «отличный мастер», а с другой - ироническое «первый писатель русский», «бездарность» и «плохой вкус», с одной стороны остроумные, увлекательные, оригинальные произведения, а с другой - штучная работа или позднее подражание.

Поневоле вспоминается вышеприведенное замечание самого Белинского, сформулированное по поводу преувеличенной похвалы, после которой, рождается такая же преувеличенная или еще более несправедливая и незаслуженная критика (БЕлинский 1977: 385).

Венгерский литературовед Агнеш Дуккон считает, что в подобной двойственности подходов критика совершенно очевидно проявляется протеистический характер (Дуккон 2010: 145) Белинского, о чем стали говорить уже в 1876 году после выхода в свет книги А. Н. Пыпина «Белинский, его жизнь и переписка». Исследователь утверждает, что ключ к критическим статьям Белинского дает его переписка «из-за страстной, исповедальной, самоанализирующей настроенности» (Дуккон 2010: 149).

Агнеш Дуккон цитирует также слова Л. Аннинского:

Его надо воспринимать вспышками - как и горел он. Белинский Россию не научил - он ее поджег, вдохновил, заразил, запалил. Это не система - это лава. Ему нельзя верить в литературных оценках - его заносит. Хотя и в оценках какая попутная меткость! (Дуккон 2010: 149).

В «Примечаниях» к четвертому тому собрания сочинений Белинского в девяти томах А. Л. Осповата и Л. С. Пустильник к причинам этого «чересчур категорического отношения Белинского к украинскому языку и литературе» относят упомянутую выше полемику об украинском языке и литератуpe, противопоставление «законсервированной», «патриархальной»украинской деревни подвергнутой «гибельному» европейскому воздействию России, а также тот факт, что «большинство украинских писателей... в то время консолидировалось вокруг ретрограднейшего „Маяка“», ярого противника «Отечественных записок». Кроме того, недостаточная теоретическая обоснованность проблемы также не давала Белинскому «возможности опереться на авторитетные исследования (ОсповАТА-Пустильник 1979: 605). И, конечно, сказывается во всем этом также уровень развития украинской литературы 30-х - начала 40-х годов XIX века.

С точки зрения двойственности подходов Белинского к украинской словесности и творчеству Григория Квитки-Основьяненко показательна история «великой схватки двух мыслителей» (ВоРоПАЕв 2016), разразившаяся между Белинским и Гоголем по поводу произведения «Выбранные места из переписки с друзьями».

Вышедшая в свет в 1847 году книга «произвела в русском образованном обществе впечатление разорвавшейся бомбы» (ВороПАЕВ 2016). Белинский подверг ее уничтожающей критике, причем опубликован был «сглаженный цензурой вариант» (ВоРоПАЕв 2016). Несправедливые упреки, тон и суждения 
Белинского глубоко потрясли Гоголя. Он написал ответ, в котором опроверг утверждения Белинского, но почему-то письма Белинскому не отправил, а разорвал на мелкие клочки, «которые, однако же, не выбросил, а аккуратно сложил в пакет». Сегодня они хранятся в Российской государственной библиотеке (ВороПАЕв 2016). Позже Гоголь написал и отправил Белинскому более короткое и эмоционально более сдержанное письмо.

В первом письме Гоголь писал:

Нет, Виссарион Григорьевич, нельзя судить о русском народе тому, кто прожил век в Петербурге, в занятьях легкими журнальными статейками. [...] А что вы представите в доказательство вашего знания человеческой природы и русского народа. [...] Какими данными вы можете удостоверить, что знаете общество? Где ваши средства к тому? Показали ли вы где-нибудь в сочиненьях своих, что вы глубокий ведатель души человека? Прошли ли вы опыт жизни? Живя почти без прикосновенья с людьми и светом, ведя мирную жизнь журнального сотрудника, во всегдашних занятиях фельетонными статьями, как вам иметь понятие об этом громадном страшилище, которое неожиданными явленьями ловит нас в ту ловушку, в которую попадают все молодые писатели, рассуждающие обо всем мире и человечестве, тогда как довольно забот нам и вокруг себя. [...] Литератор существует для другого. Он должен служить искусству, которое вносит в души мира высшую примиряющую истину, а не вражду, любовь к человеку, а не ожесточение и ненависть (Гоголь 1952: 441, 442-443, 444).

А Владимир Воропаев к характеристике ушедшего из жизни в возрасте 37 лет Белинского добавил:

Белинский был беззаветно предан русской литературе, она казалась для него высшей ценностью и святыней. Но, обладая живым умом, он был крайне наивен. [...] При этом глубокого систематического образования он не получил, Петербургский университет, в котором учился, не окончил по болезни. О России судил, видя только столичную жизнь и читая прессу (ВоРОПАЕВ 2016).

\section{Литература}

БЕлинский 1977 = БЕлинский В. Г. Литературная хроника; Репертуар русского театра; Русские журналы; «Способ к распространению шелководства» Я. Юдицкого; Утренняя заря, альманах на 1840 год, изданный В. Владиславлевым. В кн.: БЕлинский В. Г. Собрание сочинений в 9 томах. Т. 2. Статьи, рецензии и заметки. Апрель 1838 - январь 1840. Москва: «Художественная литература», 1977. $267-$ 276, 379-392, 406-412, 470-473, 510-514.

БЕлинский 1978 = БЕлинский В. Г. Полное собрание сочинений А. Марлинского; Русская литература в 1840 году; Пантеон русского и всех европейских театров; Журналистика; Сочинения Основьяненка. Пан Халявский. В кн.: Белинский В. Г. Собрание сочинений в 9 томах. Т. 3. Статьи, рецензии и заметки. Февраль 1840февраль 1841. Москва: «Художественная литература», 1978. 7-37, 178-215, 405410, 414-424, 461-462. 
БЕЛинский $1979 \mathrm{a}=$ БЕлинский В. Г. Статьи о народной поэзии. Статья 1. Общая идея народной поэзии; Русская литература в 1841 году; Ластовка. Сватання; Жизнь и похождения Петра Степанова сына Столбикова. В кн.: БЕлинский В. Г. Собрание сочинений в 9 томах. Т. 4. Статьи, рецензии и заметки. Март 1841 -март 1842. Москва: «Художественная литература», 1979. 125-145, 276-339, 416-418, 498-499.

БЕЛИнский $1979 \mathrm{~b}=$ БЕЛинский В. Г. Похождения Чичикова, или «Мертвые души». В кн.: БЕлинский В. Г. Собрание сочинений в 9 томах. Т. 5. Статьи, рецензии и заметки. Апрель 1842 - ноябрь 1843. Москва: «Художественная литература», 1979. 43-55.

БЕЛИНСКий 1981 = БЕлинский В. Г. Русская литература в 1843 году; Семейство, или домашние радости и огорчения. В кн.: БЕлинский В. Г. Собрание сочинений в 9 томах. Т. 7. Статьи, рецензии и заметки. Декабрь 1843 - август 1845. Москва: «Художественная литература», 1981. 7-58, 427-431.

БЕлинский 1982a = БЕлинский В. Г. Русская литература в 1845 году; Мысли и заметки о русской литературе. В кн.: БЕлинский В. Г. Собрание сочинений в 9 томах. Т. 8. Статьи, рецензии и заметки. Сентябрь 1845 - март 1848. Москва: «Художественная литература», 1982. 7-33, 34-60.

БЕЛИНСКИй 1982b = БЕЛИНСКИй В. Г. Письмо А. А. Краевскому (1810-1889). 19 августа 1839 г. В кн.: БЕлинский В. Г. Собрание сочинений в 9 томах. Т. 9. Письма 1829-1848. Москва: «Художественная литература», 1982. 246-247.

Бойко 1992 = Бойко Ю. Бєлінський і українське національне відродження. В кн.: Бойко Ю. Вибрані пращзі. Київ: «Медекол», 1992. 78-93.

ВОРОПАЕВ $2016=$ ВОРОПАЕВ В. А. Гоголь и Белинский: история великой схватки двух мыслителей. Фома, 12 августа 2016 г. https://foma.ru/gogol-i-belinskiy.html.

Гоголь 1952 = Гоголь Н. В. В. Г. Белинскому. Конец июля - начало августа н. ст. 1847. Остенде. В кн.: ГоГОль Н. В. Полное собрание сочинений в 14 томах. Т. 13. Письма, 1846-1847. Ленинград: Издательство АН СССР, 1952. 435-446.

Дуккон $2010=$ Dukкon A. На перекрестке жанров: атрибуты исповеди и дневника в эпистолярности Белинского. В кн.: WoŁoDźко-ButKIEWICZ Alicja (red.): Mетиаrystyka rosyjska i jej konteksty kulturowe. Warszawa, 2010. 145-153.

Дуккон 2014 = DukKON A. «Два голоса Белинского»: личность и призвание. В кн.: RAŹNY Anna (red.): Tożsamość, indywidualizm, wspolnotowość w kulturze rosyjskiej. Kraków: Wydawnictwo Universytetu Jagiellońskiego, 2014. 72-83.

КВИТКА-ОСНОВьянЕНКО 1981 = КВІтКА-ОСНОВ'янЕНКО Г. Ф. П. А. Плетневу. 15 марта 1839 г. В кн.: КВІтКА-Основ'яненКо Г. Ф. Зібрання творів у 7 томах. Т. 7. Iсторичні, етнографічні, літературно-публіцистичні статті. Листи. Київ: «Наукова думка», 1981.215.

ЛЕСКИНЕН 2018 = ЛЕскинЕН М. В. «ЗемЛя, текущая медом и молоком»: украинские земли Правобережья в представлениях региональных элит и политике имперских властей в первой половине XIX в. В кн.: Малороссы vs. украиниьь. Украинский вопрос в науке, государственной и культурной политике Российской империи и СССР. Москва: Институт славяноведения РАН, 2018. 157-202.

МАКСИМОвич 1961 = МАКСимович М. О. Бамкання в дзвони про Квітчину «Марусю». В кн.: Матеріали до вивчення історії української літератури. Т. 2. Київ: «Радянська школа», 1961. 217-221.

ОсповАТА-Пустильник 1979 = ОсПОвАТА А. Л., Пустильник Л. С. Примечания. В кн.: БЕлинский В. Г. Собрание сочинений в 9 томах. Т. 4. Статьи, рецензии и заметки. Март 1841 - март 1842. Москва: «Художественная литература», 1979. 519-627. 
СоколовА 2011 = СоколовА В. Ф. Еще раз об истоках поэмы «Тарас на Парнасе».

В кн.: Славянскія літаратуры ў кантэксие сусветнай. Матэрыялы канферэниыьі. Минск: БГУ, 2011. http://elib.bsu.by/bitstream/123456789/37355/1/Соколова.doc.

Соловьев 1898 = Соловьев Е. А. В. Г. Белинский в его письмах и сочинениях. СанктПетербург: Скоропечантня «Надежда», 1898.

Сорокин $1981=$ Сорокин Ю. С. Годы перелома. Литература и социальный прогресс.

В кн.: БЕЛИнский В. Г. Собрание сочинений в 9 томах. Т. 7. Статьи, рецензии и заметки. Декабрь 1843 - август 1845. Москва: «Художественная литература», 1981. 622-645.

\section{VIKTÓRIA LEBOVICS}

Department of Ukrainian Studies, Faculty of Humanities, Eötvös Loránd University

\section{Belinsky about Kvitka}

The Ukrainian literary critic Yuriy Boyko stated that Vissarion Grigoryevich Belinsky (1811-1848), the famous Russian literary critic harshly criticized Ukrainian writers who wrote in Ukrainian. In fact, he tried to persuade those who wrote not only in Ukrainian but also in Russian to use only the latter. Belinsky often referred to contemporary Ukrainian literature in his writings. His attitude towards Ukrainian literature and Ukrainian language was rather ambiguous. It was the manifestation of the interest in Ukraine and Ukrainian culture that existed in Russia at that time and also the continuation of the polemics about the existence of the Ukrainian language, which was quite vivid in the first half of the 19th century. The critic believed that the Little Russian language did exist but only in folk poetry of value. Since the time of Peter I, according to Belinsky, due to the separation of estates, noblemen began to speak Russian and at the same time, the Little Russian language spoken by people began to deteriorate. His categorical and unfair conclusion is that there is no Little Russian language but there is a regional Little Russian dialect, such as Belarusian, Siberian, and other similar regional dialects.

The paper is devoted to Belinsky's evaluation of the oeuvre of Hryhory Kvitka-Osnovyanenko (1778-1843), the Ukrainian writer and playwright. In his writings from 1839 to 1846 , Belinsky analyzed and sometimes only mentioned Kvitka's prosaic and dramatic works written in Russian or translated from Ukrainian into Russian. On the one hand, Belinsky characterized Kvitka as a "wonderful talent" and "an excellent master" but, on the other hand, he called him ironically "the first Russian writer", mentioning his "mediocrity" and "bad taste". On the one hand, Belinsky spoke about witty, fascinating, and original works but, on the other, he called Kvitka's writings artificial or late imitations.

The reasons for such ambiguous attitude of Belinsky towards the Ukrainian language and literature, and in particular to Kvitka's works, are the above-mentioned polemics about the Ukrainian language and literature, the juxtaposition of the patriarchal Ukrainian village subjected to the "disastrous" influence of Russia, and the fact that most Ukrainian writers grouped around the retrograde Mayak, an ardent opponent of Otechestvennye zapiski. The whole problem was not sufficiently explored theoretically, thus Belinsky had no opportunity to rely on authoritative research. The level of development of the so-called new Ukrainian literature also influenced the critic's opinion.

Keywords: Ukrainian literature, Vissarion Grigoryevich Belinsky, Hryhory KvitkaOsnovyanenko, literary criticism, literary critic, Ukrainian writer, Ukrainian language 
Open Access. This is an open-access article distributed under the terms of the Creative Commons Attribution 4.0 International License (https://creativecommons.org/licenses/ by/4.0), which permits unrestricted use, distribution, and reproduction in any medium, provided the original author and source are credited, a link to the CC License is provided, and changes - if any - are indicated. (SID_1) 